"Introduction of electronic test tools with the aim of increasing the effectiveness of the knowledge test"

\begin{tabular}{|c|c|c|}
\hline AUTHORS & \multicolumn{2}{|l|}{$\begin{array}{l}\text { Yuriy Skorin } \\
\text { Oleksandr Shcherbakov }\end{array}$} \\
\hline ARTICLE INFO & \multicolumn{2}{|c|}{$\begin{array}{l}\text { Yuriy Skorin and Oleksandr Shcherbakov (2018). Introduction of electronic test } \\
\text { tools with the aim of increasing the effectiveness of the knowledge test. } \\
\text { Development Management, 16(4), 14-25. doi:10.21511/dm.4(4).2018.02 }\end{array}$} \\
\hline DOI & \multicolumn{2}{|c|}{ http://dx.doi.org/10.21511/dm.4(4).2018.02 } \\
\hline RELEASED ON & \multicolumn{2}{|l|}{ Tuesday, 22 January 2019} \\
\hline RECEIVED ON & \multicolumn{2}{|l|}{ Thursday, 08 November 2018} \\
\hline ACCEPTED ON & \multicolumn{2}{|l|}{ Friday, 07 December 2018} \\
\hline LICENSE & \multicolumn{2}{|c|}{$\begin{array}{l}\text { This work is licensed under a Creative Commons Attribution } 4.0 \text { International } \\
\text { License }\end{array}$} \\
\hline JOURNAL & \multicolumn{2}{|l|}{ "Development Management" } \\
\hline ISSN PRINT & \multicolumn{2}{|l|}{ 2413-9610 } \\
\hline PUBLISHER & \multicolumn{2}{|c|}{ LLC "Consulting Publishing Company "Business Perspectives" } \\
\hline FOUNDER & \multicolumn{2}{|c|}{ Simon Kuznets Kharkiv National University of Economics } \\
\hline $0^{0}$ & $B$ & 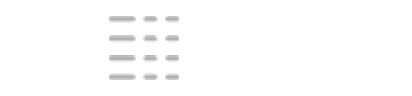 \\
\hline NUMBER OF REFERENCES & NUMBER OF FIGURES & NUMBER OF TABLES \\
\hline 24 & 1 & 1 \\
\hline
\end{tabular}

(c) The author(s) 2023. This publication is an open access article. 


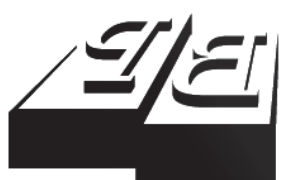

BUSINESS PERSPECTIVES

Publisher:

LLC "CPC "Business Perspectives" Hryhorii Skovoroda lane, 10, Sumy, 40022, Ukraine

www.businessperspectives.org

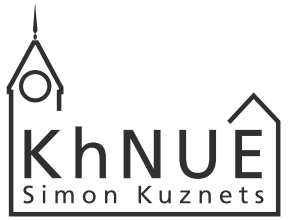

\section{S. KUZNETS KHNUE}

Founder:

Simon Kuznets Kharkiv National University of Economics, Nauky avenue, 9-A, Kharkiv, 61166,

Ukraine

http://www.hneu.edu.ua/

Received on: $8^{\text {th }}$ of

November, 2018

Accepted on: $7^{\text {th }}$ of

December, 2018

Yuriy Skorin (Ukraine), Oleksandr Shcherbakov (Ukraine)

\title{
INTRODUCTION OF ELECTRONIC TEST TOOLS WITH THE AIM OF INCREASING THE EFFECTIVENESS OF THE KNOWLEDGE TEST
}

\begin{abstract}
In article as the direction of improvement of educational process, increase of efficiency of use of perspective forms of check and an assessment of knowledge introduction in educational process of electronic means of computer testing is defined.

The study is based on the analysis of existing forms of verification and evaluation of knowledge and the main types of control measures in the study of the discipline, the allocation of advantages and disadvantages of the main forms of knowledge testing, the rationale for the choice of testing as the most effective means of testing and evaluation of students ' knowledge, the allocation of the main types of tests, the prospects of the use of electronic tests conducted using computer technology, the definition of the function of computer testing, comparative analysis of software products, providing the implementation of computer testing and selection of the most promising of them, capable, on the one hand, to simplify the testing process, and on the other hand, significantly improve the efficiency of testing and evaluation of students ' knowledge.

The study suggests:
\end{abstract}

- first, analysis, generalization and understanding of the experience of using modern methods of knowledge control, analysis of existing forms of knowledge assessment and the main types of control measures, identification of advantages and disadvantages of the main forms of knowledge testing;

- secondly, the rationale for the choice of testing as the most effective means of testing and evaluation of knowledge, the allocation of the main types of tests, the rationale for the prospects of the use of electronic tests conducted using computer technology

- third, the analysis of the conditions for the effective use of test control, the definition of the function of computer testing, comparative analysis of software products that provide the implementation of computer testing, the selection of the most promising of them that can improve the efficiency of testing and evaluation of students ' knowledge.

Keywords

JEL Classification forms of testing and evaluation of knowledge, testing of knowledge, computer testing, types of tests, preventive tests, input control, self-control, intermediate and final control, control of residual knowledge, software system for providing and conducting computer testing, collection and analysis of results

A19

Yuriy Skorin, Associate Professor of the Information Systems Department, Simon Kuznets Kharkiv National University of Economics, Ukraine.

Oleksandr Shcherbakov, Professor of the Information Systems Department, Simon Kuznets Kharkiv National University of Economics, Ukraine.

\section{(c) (i)}

This is an Open Access article, distributed under the terms of the Creative Commons Attribution 4.0 International license, which permits unrestricted re-use, distribution, and reproduction in any medium, provided the original work is properly cited.
Ю.І. Скорін (Україна), О.В. Щербаков (Україна)

\section{ВПРОВАДЖЕННЯ ЕЛЕКТРОННИХ ЗАСОБІВ ТЕСТУВАННЯ 3 МЕТОЮ ПІДВИЩЕННЯ ЕФЕКТИВНОСТІ ПЕРЕВІРКИ ЗНАНЬ}

\begin{abstract}
Анотація
У статті як напрямок удосконалення навчального процесу, підвищення ефективності використання перспективних форм перевірки та оцінювання знань визначено впровадження у навчальний процес електронних засобів комп’ютерного тестування.

Дослідження базується на проведеному аналізі існуючих форм перевірки і оцінювання знань та основних видів контрольних заходів під час вивчення дисципліни, виділенні переваг та недоліків основних форм перевірки знань, обгрунтуванні вибору тестування, як найбільш ефективного засобу перевірки і оцінювання знань студентів, виділенні основних різновидів тестів, обгрунтовані перспективність використання електронних тестів, що проводяться за
\end{abstract}


допомогою комп’ютерної техніки, визначенні функції комп’ютерного тестування, проведенні порівняльного аналізу програмних продуктів, що забезпечують реалізацію комп'ютерного тестування і виділенні найбільш перспективних з них, здатних, 3 одного боку, спростити процес тестування, а з іншого боку, істотно підвищити ефективність перевірки та оцінювання знань студентів. Дослідження передбачає:

- по-перше, проведення аналізу, узагальнення та осмислення досвіду використання сучасних методів контролю знань, проведення аналізу існуючих форм оцінювання знань та основних видів контрольних заходів, визначення переваг та недоліків основних форм перевірки знань;

- по-друге, обгрунтування вибору тестування, як найбільш ефективного засобу перевірки і оцінювання знань, визначення різновидів тестів, обгрунтування перспективності використання електронних тестів, що проводяться за допомогою комп'ютерної техніки;

- по-третє, проведення аналізу умов ефективного застосування тестового контролю, визначення функції комп’ютерного тестування, проведення порівняльного аналізу програмних продуктів, що забезпечують реалізацію комп’ютерного тестування, виділення найбільш перспективних з них, здатних підвищити ефективність перевірки та оцінювання знань студентів.

Ключові слова

Класифікація JEL форми перевірки і оцінювання знань, тестування рівня знань, комп'ютерне тестування, види тестів, превентивні тести, вхідний контроль, самоконтроль, проміжний і підсумковий контроль, контроль залишкових знань, система програм для забезпечення і проведення комп'ютерного тестування, збору та аналізу результатів

\section{ВСТУП}

Найважливішою особливістю сучасності єдосить бурхливе зростання можливостей комп’ютерної техніки, яке відкриває все нові галузі для просування комп’ютерних інформаційних технологій. Навчальний процес при цьому не $\epsilon$ винятком. В першу чергу, це стосується заходів з контролю та оцінюванню знань студентів.

Перевірка, а також оцінювання знань під час вивчення дисципліни може здійснюватися у наступних формах:

- оцінювання знань під час проведення контролю рівня підготовки студентів до проведення практичних та лабораторних робіт;

- оцінювання знань студентів під час захисту звітів з практичних та лабораторних робіт;

- оцінювання результатів виконання індивідуального завдання;

- проведення проміжного тестового контролю;

- проведення поточного модульного контролю з кожного модуля навчальної дисципліни;

- проведення підсумкового модульного контролю з навчальної дисципліни.

Таким чином, можна зробити висновок, що номенклатура форм контролю, які можуть застосовуватися викладачем, $є$ досить різноманітною, але, як свідчить практика, найчастіше використовуються такі види опитування, як письмовий та усний.

Але, на жаль, ці види опитування також мають суттєві недоліки. Так, під часпроведення усного опитування слід зазначити наявність відносно великої витрати часу заняття при відносно невеликій кількості оцінок, які виставляються за результатами опитування, а під час проведення письмових робіт, хоча кількість оцінок і зростає, хоч і не значно, але багато часу необхідно затратити на перевірку результатів опитування.

Слід зазначити, що більшість різновидів тестування можна досить легко здійснювати у разі застосовування можливостей персонального комп'ютеру, ураховуючи суттєві переваги сучасних інформаційних технологій.

Важливим $є$ і те, що під час використання подібного програмного продукту любий викладач практично може бути звільненим від рутинної, нудної праці з перевірки значної кількості схожих, однотипних завдань та тестів, яка може визвати втому, втрату уваги і, нарешті визвати помилку. 
Проведений аналіз показує, що тестування з використанням допомогою засобів обчислювальної техніки, а саме, персональних компютерів, набувають у наш час непереоціненого значення.

\section{1. ЛІТЕРАТУРНИЙ ОГЛЯА}

Підвищенню ефективності навчального процесу у цілому і ефективності контролю та оцінювання знань зокрема завжди приділялося багато уваги, чому свідчить чимала кількість статей з питань контролю та оцінки знань $[1,4-7,10,11,14-22]$. Так, різноманітні аспекти і шляхи підвищення ефективності використання перспективних форм перевірки та оцінювання знань розглядалися у роботах цілої низки вітчизняних і закордонний авторів, таких як Киричук (2002), Кондрашова (2009), Володько (2013), Пєхота (2013), Рабунський (1975), Клокар (2016), Сисоєва (1996). Але, слід зазначити, що питання, які пов’язані 3 пошуком шляхів підвищення ефективності заходів щодо контролю та оцінюванню рівня знань висвітлюються в переважній більшості робіт досить фрагментарно і вимагають більшої конкретизації та подальшого розвитку.

Саме питання, що пов'язані із розв'язанням проблем управління навчальним процесом, були розглянуті у публікаціях, такими авторами, як Бодряковим (2018), Вербицькою (2018), Моїсеєвим (2008), Поташником (2000), Шамовою (2003) та іншими.

У роботах таких авторів, як, Зорілова (2008), Каптерев (2008), Черниченко (2002) проводиться дослідження підходів, щодо професійної підготовки та інформатизації усього процесу навчання, а у роботах Тализіна (1998), Кулюткіна (2002), Беспалько (2013) досліджуються питання програмованого навчання тощо.

У дослідженнях Неймана (2000), Аванесова (2015), Єфремової (2017), Байрамової (1999), Кречетникова (2010), Майорова (2010), обговорюються питання організації тестування, а також методичні аспекти, що впливають на результати тестування, розглядаються принципи складання тестових завдань та різномонітні методики, щодо розроблення єлектронних тестів і зазначається, що тестування є однією 3 найбільш технологічних і об’єктивних форм педагогічного контролю.

\section{2. МЕТА ДОСЛІДЖЕННЯ}

Метою проведення досліджень $є$ аналіз, узагальнення та осмислення досвіду використання сучасних методів контролю знань, а також визначення основ застосування системи тестового контролю.

Така система оцінювання знань, умінь, а також навичок студентів повинна ураховувати всі види занять, які передбачені програмою навчальної дисципліни, тобто лекції, лабораторні заняття, самостійну роботу і виконання індивідуальних завдань. При цьому контрольні заходи повинні передбачати, як поточний, так і підсумковий контроль знань студентів.

Заходи щодо контролю та оцінюванню рівня знань мають виконувати наступні основні взаємопов’язані функції, а саме, діагностичну, навчальну і виховну [5].

Діагностична функція полягає у оцінюванні рівня знань, навичок, умінь студента. Вона $є$ основною, $\mathrm{i}$ найочевиднішою функцією тестування. За критеріями швидкості і об’єктивності оцінювання, тестування можна вважати найвищою формою контролю рівня знань.

Навчальна функція тестування полягає саме в мотивуванні і активізації студентів до роботи щодо засвоєння навчального матеріалу. Для посилення цієї функції тестування, можна використовувати також додаткові заходи стимулювання, наприклад, такі, як роздача загального переліку питань для самостійної підготовки, або наявність в змісті тесту підказок, проведення спільного розбору результатів тесту тощо. 
Виховна функція проявляється в чіткій періодичності і обов’язковості тестового контролю. Це, насамперед, повинно організовувати, дисциплінувати і спрямовувати роботу студентів, допомагати визначити, а також усунути деякі прогалини в знаннях, формувати прагнення до розвитку своїх здібностей.

\section{3. МЕТОАИ ДОСЛІДЖЕННЯ}

Проведення практично будь-якого наукового дослідження являє собою глибоко індивідуальний, творчий процес, успіх якого часто залежить від раціонального поєднання якісних оцінок з використанням, наприклад аналітичних методів, з кількісними оцінками, котрі спираються на конкретні факти і досвід попередніх досліджень.

Як правило, при здійсненні переважноїбільшості досліджень, зокрема досліджень, пов'язаних з розробкою концепції підвищення ефективності навчального процесу шляхом впровадження і вдосконалення перспективних форм перевірки та оцінювання рівня знань студентів, заснованих на використанні останніх досягнень компютерної техніки та інформаційних технологій, а саме електронних засобів комп'ютерного тестування, в повній мірі можуть використовуватися конкретно-наукові методи, що представляють собою сукупність теоретичних і емпіричних, тобто практичних методів.

Так, емпіричні методи, які були задіяні під часпроведення досліджень, дозволили зібрати, систематизувати і організувати емпіричний матеріал, що представляє собою усю гаму фактів, результатів спостережень i експериментів у галузі дослідження концепції підвищення ефективності навчального процесу взагалі і форм оцінювання знань студентів зокрема і, використовуючи порівняльно-зіставний метод, провести порівняння ефективності контролю знань з використанням традиційних підходів і підходів на базі використання інформаційних технологій і комп’ютерної техніки.

Теоретичні ж, тобто логічні методи, засновані на узагальненні всієї маси даних, які були отримані емпіричним шляхом, дозволили сформулювати проблему, яка полягає в необхідності вдосконалення навчального процесу, методів і засобів, щодо форм перевірки і оцінки знань студентів, у рамках зазначеної проблеми, провести аналіз публікації, сформувати гіпотезу і провести оцінювання зібраних емпіричним шляхом фактів, запропонувавши, як напрямки вирішення поставленого завдання, вибір тестування, як найбільш ефективного засобу перевірки і оцінювання знань і вибір саме електронних тестів, проведених за допомогою комп'ютерної техніки, як найбільш перспективного вигляду тестування рівня знань і умінь студентів.

\section{4. РЕЗУЛЬТАТИ}

Проведений аналіз показав, що серед безлічі форм проведення контрольних заходів перевагу слід віддати тестуванню, як найбільш ефективному засобу перевірки знань.

Тестування, у якості засобу перевірки знань студентів, як під час проведення поточного, так і підсумкового контролю матиме такі переваги [21]:

1. Тести є більш якісним та об'єктивним способом оцінювання знань завдяки застосуванню стандартизованої процедури проведення.

2. На всіх етапах тестування неможливо ввести, так звану, суб’єктивну складову в оцінку, бо вона не залежить від характеру та настрою того чи іншого викладача, його стосунків $з$ даним студентом, враженням, які склалися від відповідей на будь-які по-передні запитання.

3. Тести мають значну ємність.

4. Показники тестів орієнтовані на вимірювання ступеня, щодо визначення рівня засвоєння основних тем і розділів навчальної програми, умінь, навичок, а не на констатацію наявності у студентів певної сукупності засвоєних знань. 
5. Стандартизована форма оцінки знань дозволяє порівняти рівень досягнень будь-якого студента 3 дисципліни в цілому, або окремих його розділів із усередненим рівнем досягнень студентів у групі, на потоці й рівнями досягнень кожного з них.

6. Виконуючи підсумкову тестову роботу, кожний студент повинен використовувати знання з усіх тем програми в той час, як на усний іспит за звичай виноситься обмежена кількість тем.

7. Тести $\epsilon$, умовно кажучи, більш м’яким інструментом щодо контролю знань.

8. Тестування ставить всіх студентів у відносно рівні умови, тому що використовує загальну для всіх процедуру та загальні для всіх критерії оцінки, що приводить до зниження, так званих, нервових потрясінь, які можуть мати місце перед екзаменами.

9. Тести мають достатньо широку шкалу оцінювання знань, причому таку шкалу можна розширити не тільки угору, а і униз.

10. Гуманність, тестування полягатиме в тому, що всім без винятку студентам надаються абсолютно рівні можливості, досить великий обсяг тесту дозволяє кожному студенту показати усі свої досягнення і можливості на великому обсязі навчального матеріалу.

11. Студент повинен мати деяке право на незначну, несуттєву помилку, таке право при традиційному підході до оцінювання є відсутнім.

Можуть бути передбачені такі різновиди тестів [20]:

Перший різновид тестів - превентивні тести.

Такий різновид тестів містить анонс матеріалів, з якими має ознайомитися студент в новій дисципліні, або у новому розділі.

Також, так звані, превентивні тести ілюструють, яким саме чином студент отримає знання та навички в результаті його освоєння.

У такому різновиді тестів матеріали подаються в досить привабливій, емоційній, тобто яскравій формі, шляхом додавання до тексту кожного з запитань деяких мультимедійних об’єктів, таких як відео, аудіо, графіка тощо.

Такі тести можуть бути використовувані для, так званих, потенційних студентів, тобто тих, хто не $\epsilon$ незареєстрованними. У цьому випадку доцільно використовувати в основному мультимедійні форми надання матеріалу з обов'язковим повідомленням про помилки.

Подібні повідомлення, як правило, обумовлюються відсутністю у студента правильних відповідей і здійснюються з метою допомогти, тобто підказати студенту, який навчальний матеріал повинен вивчити даний студент, з метою запобігання помилкових відповідей.

Другий різновид тестів - вхідний контроль.

Такий різновид тестів здійснюється напередодні вивчення дисципліни, крім того він використовує загальний банк завдань, який комплектується розробником тестів.

При помилковій відповіді тест має містити посилання до низки близьких дисциплін, також тест можна провести повторно, аж до отримання позитивного результату.

Третій різновид тестів - самоконтроль.

Цей різновид тестів може здійснюватися, також і повторно, а перевіряється самим студентом.

У цьому випадку досягнення позитивного результату не є обов’язковим. 
Зазвичай, такий вид тестів виконується переду тестами проміжного, а також підсумкового контролю, він сприяє адаптації студентів до програмного інструменту тестування або для самоперевірки.

При помилковій відповіді тест повинен містити чіткі, докладні і зрозумілі коментарі.

Четвертий різновид тестів - проміжний та підсумковий контроль.

Слід зазначити, що проміжний контроль проводиться під час завершення частини курсу, а підсумковий - під час завершення усього курсу.

Такий різновид тестів повинен вимагати авторизації, при цьому зазвичай повинен накладати обмеження на того, хто тестується, наприклад, за часом, а також місцем проведення тесту.

Тобто під час тестування контролюється не тільки правильність відповіді, але і час, витрачений на відповідь.

Такий різновид тесту може передбачати індивідуальне додавання переліку питань.

Результати тестування надаються студенту у вигляді оцінки, тобто в узагальненому вигляді, але при цьому оцінка повинна структуруватись за розділами дисципліни, або тематичними блоками.

Також розробнику навчальної дисципліни, а також викладачеві важливо надавати докладну оцінку з кожного питання тесту окремо.

П’ятий різновид тестів - контроль залишкових знань.

Особливістю є те, що контроль залишкових знань може провадитися за рамками навчальної дисципліни. Цей різновид тестів доцільно використовувати під час проведення вхідного контролю для інших навчальних дисциплін.

I тут постає питання, яким чином доцільно забезпечувати тестування, традиційними, так званими, «ручними методами», або новітніми, сучасними, комп'ютерними методами. Не складний аналіз підтвердив перспективність використання для тестового контролю програмних засобів тестування, результати якого наведені на Рисунку $1[3,9,13,24]$.

Програмний продукт, який повинен забезпечити ефективну та якісну перевірку знань студентів шляхом електронного тестування, повинен відповідати наступній низці вимог.

Зазначимо, що фундаментом архітектури програмного продукту, що забезпечить реалізацію тестування, має стати принцип подвійності, різноманіття його функціонування, тобто він повинен бути доступним i може використовуватися як викладачем, так і студентом.

При цьому, відповідний вибір статусу має здійснюватися шляхом вибору типу облікового запису. Обліковий запис визначає права викладача, які включають до свого складу повний набір можливостей роботи з тестовими завданнями, такими як створення, редагування, додавання, видалення тощо.

Обліковий запис студента $є$ обмеженим, йому пропонується здійснити перевірку своїх знань шляхом відповідей на низку запитань зі створеного викладачем тесту, причому порядок питань і варіантів відповідей формується відповідним чином, наприклад, випадково.

Після завершенні тестування програма автоматично підводить підсумки, виставляє оцінку і створює звіт з проведеного тестування у форматі, наприклад, текстового файлу. 


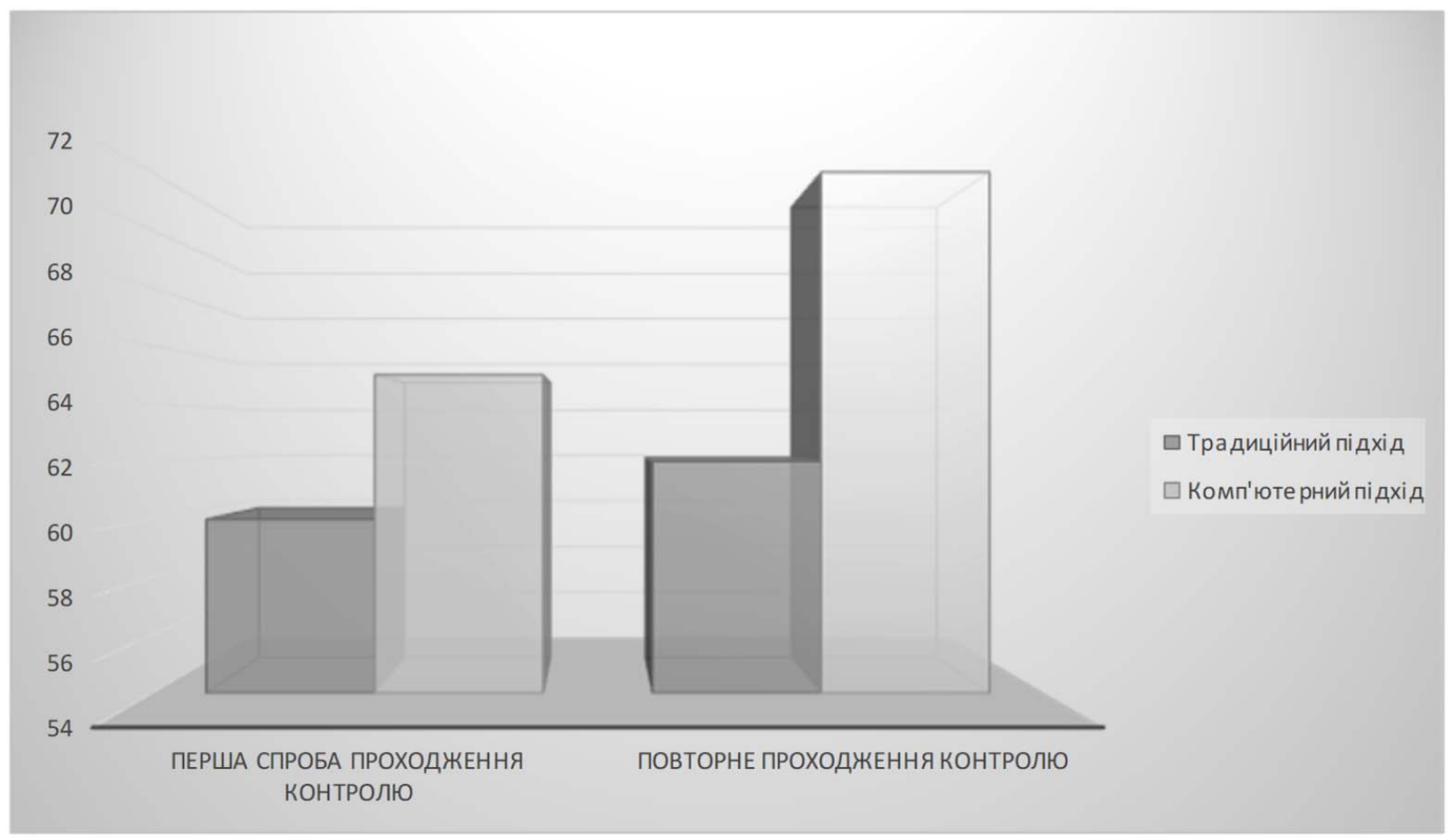

Рисунок 1. Порівняльний аналіз підходів, щодо перевірки знань

Слід приділити достатню увагу забезпеченню належного рівня захисту інформації для проведення тестування, щоб забезпечити недоступність студентів до текстів запитань, тестових завдань тощо.

Доцільним також $€$ i забезпечення програмному продукту певної універсальності застосування, наприклад, забезпечення у процесі розробки тестів можливості обрання шкали оцінювання, тобто кількості балів у системі оцінювання знань тощо.

Також програмний продукт повинен мати для користувача дружній, привітний інтерфейс, забезпечувати легкість користування навіть для тих, хто ще досить недосконало володіє комп’ютером.

Завдання для тестів можуть складатися з використанням досить великої кількості інструментів, це можуть бути, як різні редактори і програми для розробки презентацій, так і різноманітні мови програмування, а також засоби мережі інтернет.

Часто викладачі самі створюють для проведення електронного тестування своє особисте тестове середовище. При цьому, слід зазначити, що розробка досить якісного тестового інструментарію $\epsilon$ трудомісткий, досить тривалий і взагалі досить коштовний процес.

Зараз існує досить велика кількість програмних продуктів та інструментів для забезпечення проведення електронного тестування.

Такі програмні продукти можуть бути вбудованими в інші продукти, як наприклад Moodle, або автономними, як, наприклад, SunRav TestOfficePro, TestBuilder, SuperTest, Keepsoft або MyTestXPro.

Проведений порівняльний аналіз показав, що найбільш ефективним засобом тестового інструментарію $€$ MyTestXPro - система програмних продуктів для здійснення комп’ютерного тестування, а також збору, дослідженню та аналізу їх результатів, результати аналізу представлені у Таблиці 1 [3, 9, 13, 24]. 
Таблиця 1. Порівняльний аналіз програмних засобів тестування

Джерело: Узагальнено авторами

\begin{tabular}{|c|c|c|c|c|c|c|}
\hline \multirow[b]{2}{*}{$\begin{array}{c}\text { Програмні засоби } \\
\text { тестування }\end{array}$} & \multicolumn{6}{|c|}{ Критерій порівняння } \\
\hline & $\begin{array}{c}\text { Вартість } \\
\text { програмного } \\
\text { продукту } \\
\end{array}$ & $\begin{array}{c}\text { Обмеження } \\
\text { часу } \\
\text { тестування }\end{array}$ & $\begin{array}{c}\text { Використання } \\
\text { медіа }\end{array}$ & $\begin{array}{l}\text { Експорт- } \\
\text { імпорт тестів }\end{array}$ & $\begin{array}{l}\text { Створення } \\
\text { Web-тестів }\end{array}$ & $\begin{array}{l}\text { Кількість } \\
\text { тестів }\end{array}$ \\
\hline $\begin{array}{l}\text { SunRav } \\
\text { TestOfficePro }\end{array}$ & безкоштовна & + & + & + & - & не обмежена \\
\hline SunRav TestOfficePro.WEB & платна & + & + & + & + & не обмежена \\
\hline TestBuilder & платна & + & - & - & + & 256 \\
\hline SuperTest & безкоштовна & - & - & - & + & 100 \\
\hline Keepsoft & платна & - & - & - & - & 100 \\
\hline MyTestStudentX & безкоштовна & + & + & + & + & не обмежена \\
\hline MyTestXPro & безкоштовна & + & + & + & + & не обмежена \\
\hline
\end{tabular}

Програмний продукт MyTest $є$ системою програм, призначених для здійснення електронного тестового контролю, а також збору і аналізу результатів тестування, визначення оцінки обраною шкалою $[8,12]$.

MyTest включає до свого складу програму тестування студентів, редактор тестів, а також журнал результатів тестування. Важливим $€$ те, що програмний продукт MyTest постійно оновлюється, причому кожна нова версія включає до свого складу все найкраще від попередньої версії і пропонує нові можливості.

Слід згадати, що минулі версії продукту були досить простими, але дуже зручними тестовими оболонками, остання ж, поточна версія MyTestX - це вже $є$ не поодинока програма, а це $є$ досить потужний комплекс програмних продуктів для здійснення повного комп’ютерного тестування.

Програми MyTest має досить широкі можливості, що дозволяє за її допомогою забезпечувати ефективне здійснення електронного тестового контролю.

Основні функціональні можливості та переваги програмного продукту MyTest:

- можливість організації та проведення тестування в будь-яких установах, як з метою виявлення рівню знань з будь-яких навчальних дисциплін, так і з іншими навчальними цілями;

- можливість для підприємств та організацій здійснювати сертифікацію та атестацію співробітників, наприклад під час прийняття на роботу або під час вирішення питань, пов'язаних з кар'єрним ростом;

- програмний продукт є легким та досить зручним у використанні, аналіз показав, що як викладачі, так і студенти відносно легко та швидко можуть його засвоїти;

- програмний продукт здатний на реалізацію достатньо великої кількісті різновидів тестових та навчальних завдань;

- програма має сучасну модульну структуру, що здатна забезпечити її високу гнучкість та здатність до адаптації;

- програмний інструмент має досить широкі можливості та засоби для форматування тексту, як самих питань, так і варіантів відповідей;

- програма дає можливість настройки цілої низки характеристик та опцій, наприклад задати кількість балів за відповідь, змінити складність питання, додати підказку тощо;

- програма дає можливість представлення кількох варіантів питань для кожного завдання;

- у програмі можна використовувати декілька систем оцінювання рівня знань, які можна задавати або змінювати у вбудованому редакторі тесту;

- програмний засіб дозволяє завдяки модулю журналу MyTest забезпечувати дистанційний зв’язок між викладачем та студентом;

- програмний продукт MyTest забезпечує можливість організації як локального, так і мережевого тестування студентів;

- програмний продукт забезпечує підтримку декілька незалежних один від одного режимів;

- програма дозволяє встановлювати та змінювати оптимальний час на проведення тестування; 
- продукт MyTest має досить надійний захист, це стосується як змісту тестових завдань, так і результатів проведеного тестування;

- результати тестування можуть зберігатися паралельно на локальному або персональному комп'ютері викладача;

- програмний продукт MyТest передбачає декілька локалізацій, серед яких присутні такі мови, як російська, українська, білоруська, англійська тощо;

- практика свідчить про досить високу надійність роботи програмного продукту;

- програмний продукт MyTest постійно розвивається і вдосконалюється, що і $є$ найголовнішою обставиною.

Програма MyTest здатна працювати з наступними видами завдань:

1. Одиночний вибір завдання.

2. Множинний вибір завдання.

3. Встановлення порядку проходження завдання.

4. Встановлення відповідності завдання.

5. Вказівка істинності або хибності тверджень.

6. Ручне введення числа та тексту.

7. Вибір окремого місця або зони на зображенні.

8. Перестановка літерів.

9. Заповнення пропусків.

Важливим $є$ те, що у змісті тесту програма до-зволяє використовувати будь-яку кількість і будь-яких типів, при цьому можна використовувати лише один тип, а можна і всі типи одразу.

Також, у завданнях з вибором типу відповіді, наприклад, поодинокого, або множинного вибору, вказівка порядку, вказівка істинності тощо, можна використовувати аж до десяти варіантів відповіді.

Програмний продукт включає до свого складу наступні модулі:

1. MyTestStudent - модуль тестування.

2. MyTestEditor - редактор тестів.

3. MyTestServer - журнал тестування.

MyTestEditor використовується для створення змісту тестів і $€$ дуже зручним редактором тестів з досить дружнім інтерфейсом.

У програми є багато можливостей для створення та форматування, як тексту питань, так і варіантів відповідей. Програма надає можливості визначити шрифт, а також колір як символів, так і фону, розбивати текст на абзаци, застосовувати розширене форматування, широко використовувати списки, додавати малюнки, математичні формули тощо.

Також, кожному завданню можна задати складність, тобто кількість балів за вірну відповідь, а також додати підказку і надати пояснення, наприклад, якщо була зафіксована помилка в навчальному режимі, настроїти інші додаткові параметри.

Програма надає можливість використання декількох варіантів питання завдання, дозволяє зручно створювати вибірку завдань, випадково перемішувати завдання і варіанти відповідей.

Це, в свою чергу, дозволяє значно зменшити можливість списування, якщо той самий тест проходять декілька студентів або якщо тест проводиться вдруге.

MyTest дозволяє використовувати будь-яку існуючу систему оцінювання знань, наприклад, від 2-бальної 
до 100-бальної. Редактор тексту забезпечує можливість задання або налаштування системи оцінки та налаштування програми.

Модуль журналу MyTest за наявності комп’ютерної мережі, забезпечує:

1. Організацію централізованого збору, в також обробку результатів тестування, при цьому результати тестування виводяться студенту і одночасно відправляються викладачеві для оцінювання та аналізу в зручний для нього час.

2. Організацію видачі тестів студентам через мережу, причому роздачі може підлягати відразу декілька різних тестів.

3. Безпосередньо, у реальному масштабі часу, спостереження викладачем за процесом тестування та його результативністю.

Програмний продукт MyTest забезпечує підтримку декілька режимів, які є незалежними один від одного:

1. Навчальний, де студент повідомляється про кількість і якість його помилок, також йому надаються додаткові пояснення до завдання.

2. Штрафний, де за негативні результати у студента утримуються бали і студент може пропустити деякі завдання за власним вибором без втрати балів.

3. Вільний, де студент має можливість відповідати на питання в будь-якій послідовності, а також пропускати або повертатися до будь-якого питання самостійно і за власним вибором.

4. Монопольний, де вікно програми розгорнуто на увесь екран i, що є важливим, його неможливо згорнути.

Підбор і обробка контрольного матеріалу змісту тесту, може бути використана не тільки для здійснення контролю знань, а й для навчання студентів.

Тобто програма дозволяє студентам не тільки самостійно виявляти прогалини в структурі своїх знань $\mathrm{i}$ умінь, а і вживати заходів для їх ліквідації.

Таким чином, використання навчального потенціалу тестових завдань дозволяє забезпечити ефективність практичної реалізації принципу взаємозв’язку та єдності процесу навчання і процесу контролю знань.

В настройках тесту, передбачена можливість редагування часу виконання як всього тесту цілком, так і будь-якого завдання, причому час для різних тестових завдань можна виставити різним, тобто забезпечити оптимальний час тестування, нераціональність та необгрунтованість завдання якого може значно знизити показники якості тесту.

Особливо важним питанням для тестових програм $є$ питання захисту інформації. Практичне використання програмного продукту МуТеst свідчить про досить високий рівень захисту, причому це стосується як самих тестових завдань, так і результатів тестування.

Реалізація можливості задання для тесту декілька різних видів паролів, як для відкриття, так і для редагування, а також для безпосередньо тестування, призводить до того, що «зламати» тест стає практично не можливо, це стосується і ключів до правильних відповідей тестових завдань.

Важливим з точки зору захисту є те, що не тільки завдання, а і результати тестування повинні зберігатися у захищеному файлі, що забезпечує об’єктивність оцінок студентів, які завжди будуть незалежними від лояльності, або нелояльності того чи іншого викладача. Також «паралельне» зберігання результатів як на локальному комп'ютері, так і одночасно на персональному комп’ютері викладача зводить ймовірність втрати результатів практично до нуля. Програмний продукт вже продемонстрував досить високу ефективність під час застосування у вищих навчальних закладах. 
Не важко бачити, що програма компютерного тестування MyTest досягла практично досконалого стану, має більшість необхідних функції, $є$ дуже компактною, а ії функціональні можливості і простота

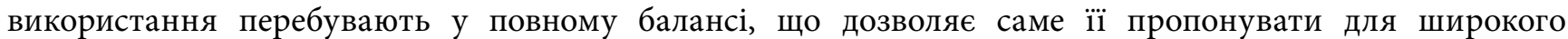
використання при здійсненні комп’ютерного тестового контроля у вищих навчальних закладах.

\section{ВИСНОВКИ}

Підводячи підсумки, насамперед, слід підкреслити новизну проведених досліджень. На думку Бермус, під новизною дослідження розуміється «наскільки є сучасними і оригінальними використовувані в дослідженні уявлення і методи» [2]. Солнишкову видається цілком правомірним введення цих критеріїв в оцінювання наукової новизни поряд з фіксацією фактів приросту знань тощо [23].

Новизна проведених досліджень полягає у тому, що було проведено комплексне дослідження теоретичних i практичних аспектів підвищення ефективності навчального процесу в загалі і форм контролю знань студентів зокрема, в результаті якого на основі порівняльно-зіставного методу був проведений порівняльний аналіз ефективності використання традиційних, так званих, «ручних» підходів і підходів на базі використання останніх досягнень інформаційних технологій і компютерної техніки, а також внесені конкретні пропозиції щодо комплексного використання електронних засобів контролю знань 3 урахуванням їх технічних характеристик, розглянуто комбінований метод контролю знань, що поєднує в собі всі позитивні риси традиційних і комп’ютеризованих підходів до вирішення питань контролю знань, що повністю збігається з поглядом на критерії новизни наукових досліджень Бермус [2] і Солнишкова [23].

Сучасність потребує зробити досить рішучий стрибок від традиційних, так званих, «ручних» методів і форм навчання та контролю знань до новітніх, більш ефективних, тобто потребує створення нової системи контролю знань, з використанням останніх досягнень компютерної техніки і інформаційних технологій, яка б забезпечила об’єктивне оцінювання, як знань і умінь, так і навичок студентів, повністю виключаючи при цьому елементи суб'єктивізму.

Необхідно таким чином організувати всі етапи навчального процесу, щоб система контролю знань природньо і навіть непомітно включалася в загальну систему навчання в якості обов'язкового функціонального компоненту, який би забезпечував його цілісність, об’єктивність, бесперевність i цілеспрямованість.

Найбільш ефективним на теперішній час методом оцінювання знань, умінь та навичок студентів $\epsilon$ тестування, бо воно є більш якісним та більш об'єктивним способом оцінювання знань, практично виключають суб'єктивну складову, мають значну ємність, відрізняються більш м'яким підходом до контролю знань, стандартизованою формою оцінки знань, яка дозволяє здійснити рейтингове порівняння досягнень будь-якого студента із усередненим рівнем досягнень студентів у групі, на потоці тощо, ставить всіх студентів у рівні умови, тому що використовує загальну для всіх процедуру та загальні для всіх критерії оцінки, має достатньо широку шкалу оцінювання знань, відрізняється гуманністю, тому що всім студентам надаються абсолютно рівні можливості і при цьому ураховується, що студент повинен мати право на незначну, несуттєву помилку, таке право при традиційному підході до оцінювання $\epsilon$ відсутнім, значно спрощує процес перевірки робіт, дає можливість перевіряти великій об’єм матеріалу за відносно невеликий проміжок часу, дозволяє отримати результати оцінювання знань практично відразу по завершенні тесту.

Наприкінці слід зазначити, що застосування сучасних компютерних інформаційних технологій в навчальному процесі дозволить, з одного боку, суттєво підвищить ефективність та значно спростить тестовий контроль знань студентів, з іншого боку, дасть відчутний поштовх до розробки цілої низки подібних програмних продуктів. 


\section{СПИСОК ЛІТЕРАТУРИ}

1. Alekceychuk, I. C. (2000). Про технологію створення системи тестування [Pro tekhnolohiyu stvorennya systemy testuvannya] (pp. 4392). Novi tekhnolohii navchannia. Kyiv: NMTSVD.

2. Bermus, A. G. (1999). Общие основы педагогики [Obshchiye osnovy pedagogiki] (114 p.). Rostov-na-Donu: Izd-vo Rostov, gos. ped. un-ta.

3. Bukhanevych, N. V. (2007). Контроль та оцінка навчальних досягнень учнів [Kontrol ta otsinka navchalnykh dosyahnen uchniv]. Retrieved from http://studentam.net.ua/content/view/7556/97/

4. Bulakh, I. Е. (2006). Основи педагогічного оцінювання [Osnovi pedahohichnoho otsinyuvannya] (pp. 36-91). Kyiv.

5. Denglisch (2016). Сучасні методи контролю і оцінки знання учнів [Cuchacni metody kontroliu i otsinky znannia uchniv]. Retrieved from https://denglisch-vid-desyatnik.webnode.com.ua/news/suchasni-metodi-kontrolyu-i-otsinki-znannya-uchniv/

6. Doroshenko, U., Rotayenko, P., \& Semenyuk N. (2005). Педагогічна діагностика та оцінювання результатів тестування [Реdahohichna diahnostika ta otsinyuvannya rezultativ testuvannya]. Zavuch, 20-21, 56-60.

7. Duzhenkov, V. D. \& Panacyuk, T. I. (2006). Деякі аспекти методики складання тестових завдань [Deyaki aspekty metodyky skladannya testiv zavdannya]. Orhanizatsiia navchalno-vykhovnoho protsecu, 8, 104-109.

8. Klyaksa.net. Форум MyTestXPro [Forum MyTestXPro]. Retrieved from http://klyaksa.net-/forum/index.php?topic=317-\&mode_ forum $=$ posts

9. Kuzma, K. T. (2017). Computer technologies of verification of knowledge based on the method of sequential analysis. Radio Electronics, Computer Science, Control, 3, 121-129. https://doi.org/10.15588/1607-3274-2017-3-14

10. Kytayhorodcka, H. О. (2004). Контроль знань у курсі хіміi у профільних класах [Kontrol znan и kursi khimiyi u profilnikh klasakh] (pp. 76-82).

11. Mashtaler, Н. (2004). Тематична атестація - новий підхід до контролю й оцінювання навчальних здобутків учнів [Тетаtусhnе atestatsiya - noviy pidkhid do kontrolyu y otsinyuvannya Navchalnykh zdobutkiv uchniv]. Ukraincka literatura $v$ zahalnoocvitnii shkoli, $9,42-45$.

12. MyTestXPro. Компьютерное тестирование знаний MyTestX [Kompyuternoye testirovaniye znaniy MyTest]. Retrieved from http:// mytest.klyaksa.net

13. Navchalni materialy onlain. Методи і форми контролю успішності студентів [Metody i formy kontrolyu uspishnosti studentiv]. Retrieved from https://pidruchniki.com/70171/pedagogika/metodi_formi_kontrolyu_uspishnosti_studentiv

14. Polyakova, A. A. (2000). Рейтинговая система контроля и оценки знаний по педагогике: Практикум для педагогов, студентов и yчamuxся [Reytinhovaya systema kontrolya i otsinky znan' po pedahohitsi: Praktykum dlya pedahohov, studentov i uchniv]. Mockva: Mock. gor. ped. ob-vo.

15. Savchenko, О. (1997). Контроль та оцінка результатів навчання [Kontrol ta otsinka rezultativ navchannya] (pp. 122-137). Kyiv: Abryc.

16. Skorin, Yu. I. (2003). Методичні підходи щодо компютеризації навчального процесу [Metodichni pidkhodi shchodo kompyuterizatsiyi navchalnoho protsesu]. Navchalno-vykhovnyi protsec: metodyka, docvid, problemy, 6(91), 4-6.

17. Skorin, Yu. I. (2004). Використання комп'ютерних технологій для побудови автоматизованих систем віддаленого навчання [Vikoristannya kompyuternikh tekhnolohiy dlya pobudovi avtomatizovanikh system viddalenoho navchannya]. Systemy obrobky informatsiyi, 4, 196-200.

18. Skorin, Yu. I. (2004). Шляхи підвищення ефективності дипломного і курсового проектування [Shljahu pidvyshchennya efektivnosti diplomnoho y kursovoho proektuvannya]. Navchalno-vykhovnyi protsec: metodyka, docvid, problemy, 2-3(93-94), 22-23.

19. Skorin, Yu. I. (2008). Упровадження в навчальний процес засобів інформаційного супроводження навчальних занять [Uрrovadzhennya v navchalnyy protses zasobiv informatsiynoho suprovodzhennya Navchalnykh zaynyat]. Upravlinnia rozvytkom, 15, 145-146.

20. Skorin, Yu. I. (2013). Робоча програма навчальної дисиипліни «Технології тестування програмних продуктів» для студентів напряму підготовки «Комп'ютерні науки» [Robocha prohrama navchalnoyi dystsypliny «Tekhnolohiyi testuvannya prohramnikh produktiv» dlya studentiv napryamu pidhotovki «Kompyuterni nauky»] (40 p.). Kharkiv: KhNEU.

21. Skorin, Yu. I., Fedko, V. V., \& Shcherbakov, O. V. (2011). Робоча програма навчальної дисиипліни «Методи та засоби комп'ютерних інформаційних технологій» для студентів напряму підготовки «Комп'ютерні науки» [Robocha prohrama navchalnoyi dystsypliny "Metody ta zasoby kompyuternikh informatsiynikh tekhnolohiy" dlya studentiv napryamu pidhotovki "Kompyuterni nauky"] (48p.). Kharkiv: KhNEU.

22. Skorin, Yu. I., Stadnyk, V. V., \& Shcherbakov, O. V. (2010). Інформаційне супроводження навчального процесу [Informatsiyne suprovodzhennya navchalnoho protsesu]. Upravlinnia rozvytkom, 7(88), 273-274.

23. Solnyshkov, M. Е. (2009). Критерии новизны научно-педагогических исстедований [Kriterii novizny nauchno-pedagogicheskikh issledovaniy]. Retrieved from https://cyberleninka.ru/article/v/kriteriy-novizny-nauchno-pedagogicheskih-issledovaniy

24. Ukrayinskyy tsentr otsinyuvannya yakosti osvity. Retrieved from http://testportal.gov.ua/ 